The Relation Between Dating Violence Victimization and Commitment Among Turkish College Women: Does the Investment Model Matter?

By: Ezgi Toplu-Demirtas, Zeynep Hatipoğlu-Sümer, and Jacquelyn W. White.

Toplu-Demirtaş, E., Hatipoğlu-Sümer, Z., \& White, J. W. (2013). The Relation Between Dating Violence Victimization and Commitment Among Turkish College Women: Does the Investment Model Matter? International Journal of Conflict and Violence, 7, (2), 203-215. https://doi.org/10.4119/ijcv-3019

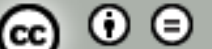

${ }_{\mathrm{EY}}$ This work is licensed under a Creative Commons Attribution-NoDerivatives 4.0 International License.

\begin{abstract}
:
The present study explored the sexual, physical, psychological, and overall dating violence experiences, and related these experiences to Investment Model variables among Turkish college women. Three hundred and ninety dating women from four universities in Ankara, Turkey completed the Satisfaction, Investment, Alternatives, and Commitment subscales from the Investment Model Scale and the Sexual Coercion, Physical Assault, and Psychological Aggression subscales from the Revised Conflict Tactics Scale. 79.5 percent reported at least one incident of violence in a dating relationship within the previous year. Regression analyses indicated that satisfaction fully mediated the relations between physical, psychological, and overall dating violence victimization and commitment, but not for sexual victimization. The results suggest that future research should explore the possibility that the dissatisfaction women experience may be related to an increased likelihood of relation termination.
\end{abstract}

Keywords: dating violence | Turkey | victimization | Investment Model

Article:

$* * *$ Note: Full text of article below 


\section{The Relation Between Dating Violence Victimization and Commitment Among Turkish College Women: Does the Investment Model Matter?}

Ezgi Toplu-Demirtaş, Department of Educational Sciences, Middle East Technical University, Ankara, Turkey Zeynep Hatipoğlu-Sümer, Department of Educational Sciences, Middle East Technical University, Ankara, Turkey Jacquelyn W. White, Department of Psychology, University of North Carolina at Greensboro, United States

\section{Vol. 7 (2) 2013}

Editorial (p. 197)

Focus Section:

Focus: Intimate Partner

Violence
Guest Editorial: Intimate Partner Violence as a Global Problem - International and Interdisciplinary

Perspectives Barbara Krahé / Antonia Abbey (pp. 198 - 202)

The Relation Between Dating Violence Victimization and Commitment Among Turkish College Women: Does the Investment Model Matter? Ezgi Toplu-Demirtaş / Zeynep Hatipoğlu-Sümer / Jacquelyn W. White (pp. 203 - 215)

Women, Violence, and Social Change in Northern Ireland and Chiapas: Societies Between Tradition and Transition Melanie Hoewer (pp. 216 - 231)

Intimate Partner Violence Against Disabled Women as a Part of Widespread Victimization and Discrimination over the Lifetime: Evidence from a German Representative Study Monika Schröttle / Sandra Glammeier (pp. 232 - 248)

Perceptions of Gay, Lesbian, and Heterosexual Domestic Violence Among Undergraduates in Sweden Ali M. Ahmed / Lina Aldén / Mats Hammarstedt (pp. 249 - 260)

College Students' Perceptions of Intimate Partner Violence: A Comparative Study of Japan, China, and the United States Toan Thanh Nguyen / Yasuko Morinaga / Irene Hanson Frieze / Jessica Cheng / Manyu Li / Akiko Doi / Tatsuya Hirai / Eunsun Joo / Cha Li (pp. 261 - 273)

Self-efficacy in Anger Management and Dating Aggression in Italian Young Adults Annalaura Nocentini / Concetta Pastorelli / Ersilia Menesini (pp. 274 - 285)

Reactions to Provocation and Feelings About Aggression in an Indian sample VanLal Thanzami / John Archer (pp. $286-297$ )

Transitional Justice and the Quality of Democracy Anja Mihr (pp. 298 - 313) 


\title{
The Relation Between Dating Violence Victimization and Commitment Among Turkish College Women: Does the Investment Model Matter?
}

\author{
Ezgi Toplu-Demirtaş, Department of Educational Sciences, Middle East Technical University, Ankara, Turkey \\ Zeynep Hatipoğlu-Sümer, Department of Educational Sciences, Middle East Technical University, Ankara, Turkey \\ Jacquelyn W. White, Department of Psychology, University of North Carolina at Greensboro, United States
}

The present study explored the sexual, physical, psychological, and overall dating violence experiences, and related these experiences to Investment Model variables among Turkish college women. Three hundred and ninety dating women from four universities in Ankara, Turkey completed the Satisfaction, Investment, Alternatives, and Commitment subscales from the Investment Model Scale and the Sexual Coercion, Physical Assault, and Psychological Aggression subscales from the Revised Conflict Tactics Scale. 79.5 percent reported at least one incident of violence in a dating relationship within the previous year. Regression analyses indicated that satisfaction fully mediated the relations between physical, psychological, and overall dating violence victimization and commitment, but not for sexual victimization. The results suggest that future research should explore the possibility that the dissatisfaction women experience may be related to an increased likelihood of relation termination.

Evidence suggests that dating violence is a pervasive global problem among college students (Chan, Straus, Brownridge, Tiwari, and Leung 2008). However, little is known about such victimization among college women in Turkey. Dating violence may include sexual, physical, or psychological abuse. According to Chan et al's comprehensive international dating violence study of nearly 16,000 college students from twenty-one countries, a high percentage of women reported physical and sexual dating violence despite large differences among countries. Their results indicate that the dating violence problem is not limited to industrialized Western countries. In another large-scale international study using data obtained from thirty-one universities in sixteen countries, Straus (2004) reported high rates of physical violence against dating partners. Two recent studies suggest that dating violence is a pervasive problem among Turkish university students as well. In one study of 240 college women, 21.6 percent reported that they experienced violence in their current dating relation- ship (Aslan, Vefikuluçay, Zeyneloğlu, Erdost, and Temel 2008). In a more recent survey with 337 dating college women, 29.1 percent reported having experienced sexual victimization at least once in their lifetime. This percentage climbed to 77.4 percent for psychological victimization. The rate for physical victimization was 37.1 percent (Toplu and Hatipoğlu-Sümer 2011). Taken together, the available empirical evidence demonstrates that Turkish college women are at high risk for victimization. It is likely that the cultural context of violence against women provides a backdrop for understanding dating violence among Turkish college students.

\section{The Turkish Context of Violence against Women}

Since the foundation of the Turkish Republic in 1923, Turkish women have gradually been granted relatively equal legal rights, with a number of legal amendments being implemented to advance women's well-being. To name a few, Turkey signed the Convention on the Elimination of 
All Forms of Discrimination against Women in 1985, and the Beijing Declaration in 1995. With the establishment of the Directorate-General on the Status and the Problems of Women in 1990, important steps have been taken at the governmental level as well. The adoption of the "Law for the Protection of the Family" in 1998, the new "Penal Code" in 2005, the "Prime Ministry's Circular No. 26218" in 2006, and the new "Law for the Protection of the Family and Prevention of Violence Against Women" in 2012 are the latest achievements indicating that prevention of violence against women is a state policy (Türkiye Büyük Millet Meclisi [TBMM] 2012).

Despite all the measures taken to prevent violence at the state level, in practice, the traditional value structure seems to resist improving the quality of life of Turkish women. Violence against women remains a significant problem and adversely affects their health and well-being. According to the results of a nationwide representative "Violence against Women in Turkey" study ( $=1800$; Altınay and Arat 2009), approximately one out of every three Turkish women has been the victim of intimate partner violence/ domestic violence, and much of women's lives is strictly controlled by their husbands. Altinay and Arat found that almost half of the women who had been physically abused by their partners had never disclosed this to anyone. The study also revealed that one fourth of women did not feel adequately equipped to deal with present or future violence, stating that they could do nothing if their partner were to beat them. Social pressures on women make it very hard for them to leave an abusive relationship. Even after they leave, they are not safe. Divorced/separated women are more likely to be the victims of intimate partner violence than married women. A study conducted by the Turkish Republic Prime Ministry, Directorate-General on the Status and Problems of Women, found that 73 percent of divorced/separated women had experienced either physical or sexual violence (Turkish Republic Prime Ministry 2009).

The data available on violence against women in Turkey, in the context of Turkey's patriarchal values, raise questions about the nature of beliefs about relationships, gender roles, intimacy, and violence in college students' dating relationships. Gender inequality in patriarchal societies has been cited as one of the factors that influences the prevalence of violence against women (Hortaçsu, Kalaycıŏlu, and Ritterberger-Tilıç 2003). Turkish culture generally has been described as traditional, patriarchal, and authoritarian (Fişek 1982).

In traditional Turkish families, family honor is regarded as extremely important: "Honor may refer to a man's reputation as a participant in the community (şeref), or it may refer to his reputation as determined by the chastity of the women in his family (namus)." (Özgür and Sunar 1982, 350). The preservation of female virginity has also been equated with family honor. Defense of family honor is accepted as the man's duty (Özgür and Sunar 1982). Women who engage in premarital sexuality may be subjected to various sanctions, including "honor killing," physical abuse, and involuntary virginity examinations. In addition, they are also viewed as less desirable marriage partners (Sakall1-Uğurlu and Glick 2003). The double standards for male and female sexuality, virginity, and traditional myths regarding the hymen are still prevalent even in the better-educated sections of society (Cok and Gray 2007; Eşsizoğlu et al. 2011). Thus, while recent legislative initiatives have the effect of improving the status of women, the influence of patriarchal values and threats of serious reprisals for violation of gender roles still creates a precarious position for Turkish college women.

Research on dating violence among Turkish college women is in its infancy. Hence, there are many unanswered questions. For example: Does violence in a relationship with a sexual component have different consequences? Do victims report offenses? What factors affect the likelihood of the woman leaving an abusive relationship? How do young women make sense of the experience, given the contradictory societal expectations that men should protect women while holding women responsible for victimization by their protectors? To begin to explore these questions, the present study focused specifically on the relation between dating violence and commitment to a relationship. Given the correlational nature of the study we cannot determine whether commitment to a relationship increases risk of victimization, that is, male partners feel it is "safe" to be abusive, or, alternatively, victimization alters perceptions of 
the relationship, including commitment, as a coping strategy to endure the relationship, because cultural factors may make it too difficult to leave. We begin by examining the components of commitment - relationship satisfaction, investment, and perceived alternatives.

\section{Investment Model and Dating Violence Victimization}

The Investment Model (Rusbult 1980, 1983) has become the major theory used to understand how women deal with abusive relationships, in light of growing evidence that many women stay in abusive relationships, if only for a short time (Katz, Kuffel, and Brown 2006; Rhatigan, Street, and Axsom 2006). The model has been of value in studying responses to dissatisfaction in romantic involvements (Rusbult, Zembrodt, and Gunn 1982), stay and leave behaviors in abusive relationships (Katz, Kuffel, and Brown 2006; Rhatigan and Street 2005; Rusbult and Martz 1995), willingness to sacrifice (Etcheverry and Le 2005), forgiveness (Cann and Baucom 2004), and dating infidelity (Drigotas, Safstrom, and Gentilia 1999).The value of the Investment Model over violence-specific theories of women's responses to abuse lies in its focus on social, contextual, and interdependence factors rather that individual variables that are open to victim-blaming interpretations (Edwards, Gidycz, and Murphy 2011; Rhatigan, Street, and Axsom 2006). The theory suggests that satisfaction, investment, and quality of alternatives combine to predict relationship commitment and greater commitment results in greater difficulty terminating the relationship.

As an extension of Interdependence Theory (Kelley and Thibaut 1978), the Investment Model developed by Rusbult $(1980,1983)$ consists of four components: commitment, level of satisfaction, size of investment made, and perception of the availability of alternatives. Satisfaction means a general evaluation of the relationship with its rewards and costs. Investment, which may be financial (money), temporal (time), and/or emotional (effort), refers to how much a person has already invested in the relationship. Quality of alternatives refers to a comparison with potential alternative relationships (i.e., is there a better available alternative?). Commitment involves intentions to stay in a relationship, feelings of psychological attachment, and a positive orientation toward a long-term relationship
(Rusbult, 1980, 1983). It is theorized that higher commitment is determined by greater satisfaction, heavier investment, and poorer alternatives (Rusbult 1980, 1983), and that commitment is lower among victimized than nonvictimized women (Rhatigan et al. 2006).

Rhatigan and Street's (2005) correlational study conducted in United States is of most relevance to the present study, and methodologically similar, although they did not include sexual victimization. They reported that higher levels of abuse were associated with lower levels of commitment, but when they looked at each type of abuse, the picture became more complicated. They found negative correlations between physical and psychological violence and satisfaction, as well as a negative correlation between physical abuse and investment, but a positive correlation between investment and psychological abuse. They also reported that satisfaction, but not investment or quality of alternatives, mediated the relation between abuse and commitment, suggesting that relationship satisfaction is critical to feelings of commitment.

In the light of findings to date, the current study seeks to investigate the relation between Investment Model (i.e., satisfaction, investment, perceived alternatives, and commitment) and dating violence victimization (i.e., sexual, psychological physical, and overall dating violence victimization) among Turkish college women. In Turkey, the Investment Model has been used to examine issues related to intimate relationships, such as the perception of religiosity and stereotypes about romantic relationships (Okutan and Büyükşahin-Sunal 2010), future time orientation in romantic relationships, love attitudes, and attachment (Büyükşahin and Hovardaoğlu 2007), and positive illusions in marriages and causality and responsibility attributions (Akbalık-Doğan and Büyükşahin-Sunal 2011), but not dating violence. Given the Turkish cultural context of intimate relationships, the relative importance of the relation between dating violence and satisfaction, investment, quality of alternatives, and commitment may differ from the pattern observed by Rhatigan and Street (2005). Thus, building on Rhatigan and Street, which is the only study to date of which we are aware that explicitly examined each type of dating violence in relation to the components of 
commitment, the present study seeks to expand the findings to a different cultural context.

Firstly, we hypothesize, like Rhatigan and Street (2005), that there will be a negative correlation between satisfaction and victimization, and commitment and victimization. Secondly, when commitment is regressed on victimization and satisfaction, satisfaction will be positively related to commitment, leaving victimization non-significant, and thus will mediate the relationship between victimization and commitment (see Figure 1). Lastly, although Rhatigan and Street (2005) did not find a mediating role for investment or quality of alternatives, we remain open to the possibility that these may be relevant in the Turkish context. Given the strength of patriarchal values in Turkey, we expect alternatives and investment to also be important. Turkish college women who have engaged in any pre- marital sexual activity (vaginal or not) may feel they have no other alternatives, thus staying in the relationship and investing time, effort, and energy. Fewer perceived alternatives and greater investment (due to sexual involvement) may increase the likelihood of tolerating violence. Additionally, unlike Rhatigan and Street, we included sexual victimization in the present study. Because of the importance of virginity in Turkey, we expect that correlations between sexual victimization and the Investment Model may differ from those for physical and psychological victimization, although there is no current evidence to suggest that. Because we wanted to ensure that reports of victimization in the previous year refer to the same relationship as the Investment Model variables, we divided the sample into two groups based on duration of the relationship: one year and less or longer than one year. Only data from the latter were included in our test of the hypotheses.

Figure 1: Investment Model variables mediating the relationship between victimization and commitment

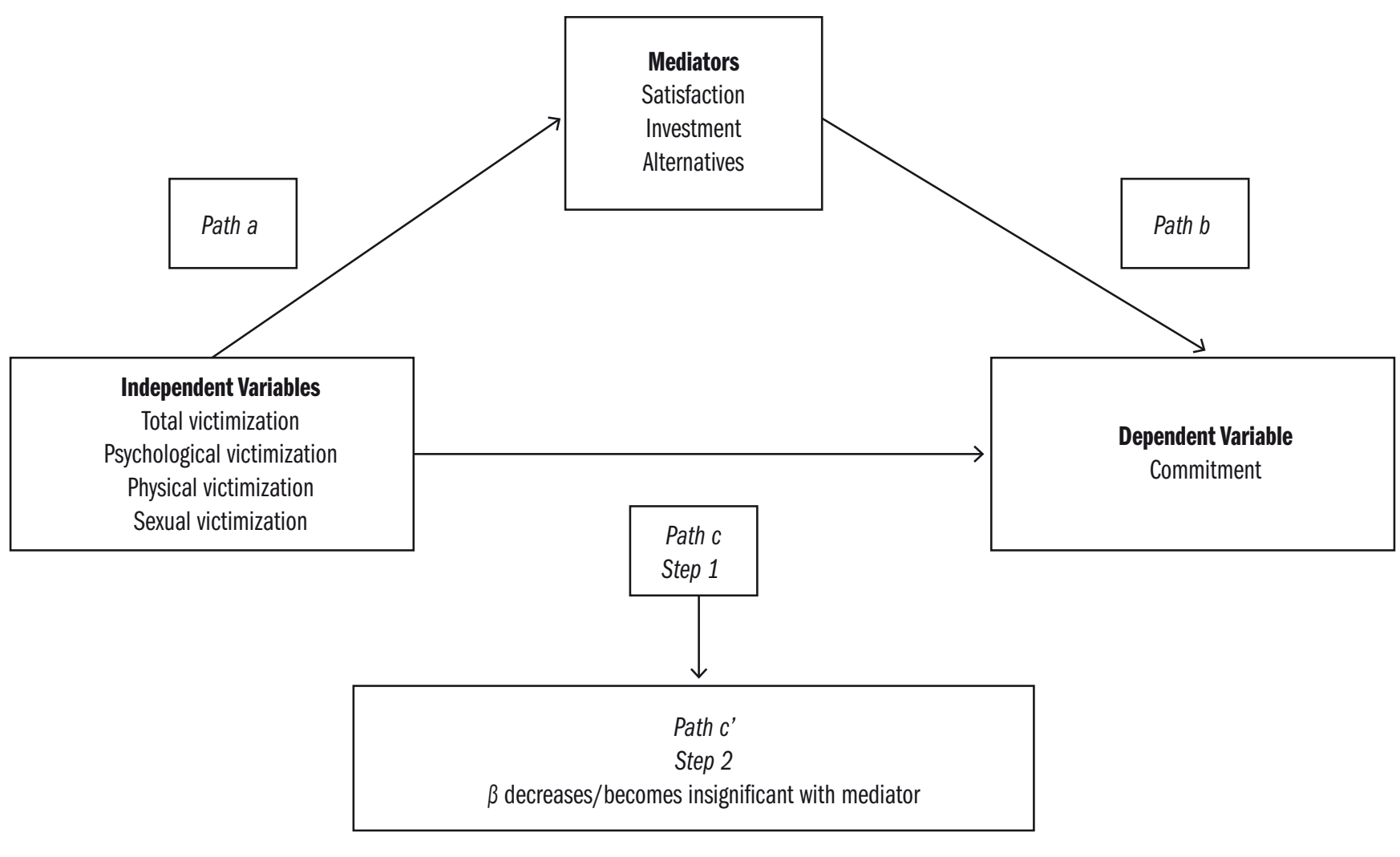




\section{Method}

\subsection{Participants}

Three hundred and ninety dating women from four state universities (distributed 63.8 percent, 15.6 percent, 12.3 percent, 7.7 percent, with 0.6 percent not specified) in Ankara voluntarily participated: 14 prep students (in preparatory classes; 3.6 percent), 82 first-years (21.0 percent), 146 sophomores (37.4 percent), 60 juniors (15.4 percent), 43 seniors (11.0 percent), 32 master's level (8.2 percent), and 13 doctoral level (3.3 percent). The mean age of the participants was $21.04(\mathrm{SD}=2.16)$ with an age range between 17 and 30. Data for the study were collected during the fall and spring semesters of the 2010-2011 academic year. Surveys were administered to the participants during regular class hours after required permission had been obtained from the Human Subjects Ethics Committee (i.e., the institutional review board in Turkish universities) and course teachers. Classes in which data were collected included Introduction to Education, Educational Psychology, Classroom Management, Guidance, Principles of Kemal Ataturk, History of the Turkish Revolution, and Turkish, just to name a few. Clear instructions and information about the purpose of the study were given and anonymity and confidentiality were assured on the consent form. Participants were instructed not to involve partners/ friends in the activity. It took the participants approximately 15 to 20 minutes to complete the survey.

\subsection{Data Collection Instruments}

\subsubsection{Demographic Information}

A demographic information form was used to obtain the respondents' sex, age, university, year, and information related to their relationship characteristics (e.g., length of relationship in months, relationship status).

\subsubsection{Dating Violence Victimization}

Three subscales of the Turkish version (Turhan, Guraksin, and Inandi 2006) of the Revised Conflict Tactics Scale (Straus et al. 1996) were used to assess physical, sexual, and psychological victimization. Turhan, Guraksin, and Inandi (2006) used the forward translation/back-translation procedure to ensure the equivalency of the English and Turkish versions of the whole Revised CTS (CTS2). The results of the explanatory analyses of the whole scale were con- sistent with the original scale, revealing a multidimensional factor structure similar to the original one. The scale as a whole demonstrated satisfactory evidence of validity and reliability. For each item the respondents reported the frequency with which they experienced the event on an eightpoint scale: 0 (this has never happened), 1 (once in past year), 2 (twice in past year), 3 (3 to 5 times in past year), 4 (6 to 10 times in past year), 5 (11 to 20 times in past year), 6 (more than 20 times in past year), 7 (not in the past year but has happened previously). The twelve-item Physical Assault Scale was used to measure physical dating violence victimization with items such as: "My partner threw something at me that could hurt" and "My partner slapped me." The analysis yielded an internal consistency of .91 for physical assault. The eight-item Psychological Aggression Scale was used to assess psychological dating violence victimization, and included items such as: "My partner shouted or yelled at me" and "My partner said something to spite me." Cronbach's alpha for the psychological aggression scale was .79. The seven-item Sexual Coercion Scale was used to measure sexual dating violence victimization. One of the items was about the use of condoms. The other six were related to verbal insistence (two items; one for vaginal, one for anal/ oral sex), use of force (two items; one for vaginal, one for anal/oral sex), and the use of threats (two items; one for vaginal, one for anal/oral sex). Examples included "My partner insisted on sex when I did not want to (but did not use physical force)", "My partner used force (like hitting, holding down, or using a weapon) to make me have sex," and "My partner used threats to make me have sex." In the present study Cronbach's alpha was .80 .

The CTS subscales were scored in two ways. First, to determine the percentage of women experiencing each type of victimization, a dichotomous $0 / 1$ prevalence variable was created to categorize whether or not sexual, physical, and psychological victimization had occurred during the past twelve months (Straus et al. 1996). Because we were interested in victimization during the previous year (in the last twelve months), we coded category 7 as 0 , as recommended by Straus et al. (1996). For each subscale, responses were summed to create an index of degree of victimization in the past year. Higher scores indicate more victimization. Finally, an index of total victimization was 
obtained by summing the sexual, physical, and psychological victimization scores.

\subsubsection{The Investment Model}

Büyükşahin, Hasta, and Hovardaoğlu (2005) adapted and evaluated the satisfaction, investment, and quality of alternatives subscales of Rusbult, Martz, and Agnew's (1998) Investment Model Scale (IMS) in terms of validity and reliability among Turkish university students. The commitment subscale was later translated by Büyükşahin and Taluy (2008). All the items make use of nine-point Likert scales with 1 indicating "disagree completely" and 9 indicating "agree completely." Satisfaction is defined as the number and magnitude of resources tied to a relationship, measured using a five-item scale. Items include "Our relationship does a good job of fulfilling my needs for intimacy, companionship, etc." and "My relationship is close to ideal." Higher scores indicate greater satisfaction. Investment is measured using a five-item scale that focuses on resources put into the relationship. Items include "I have put a great deal into our relationship that I would lose if the relationship were to end" and "Many aspects of my life have become linked to my partner (recreational activities), and I would lose all of this if we were to break up." Higher scores indicate greater investment. Quality of Alternatives is measured using a five-item scale and assesses perceptions of availability of other partners. Items include "The people other than my partner with whom I might become involved are very appealing" and "If I weren't dating my partner, I would do fine - I would find another appealing person to date." Higher scores indicate higher-quality alternatives. Commitment is measured using a seven-item scale that assesses commitment to the relationship. Items include "I want our relationship to last for a very long time" and "It is likely that I will date someone other than my partner within the next year." Higher scores indicate greater commitment. In the current study, Cronbach's alpha for satisfaction, quality of alternatives, investment, and commitment was $.94, .85, .88$, and .93 , respectively.

\section{Results}

Analysis proceeded in three steps. First, we determined that there were no significant differences between the samples obtained at the different universities, and were thus able to collapse the data from all four universities for all analyses. We also assessed for age differences between victimized and non-victimized women, and found only one. The psychologically victimized group was younger, but the magnitude of the difference was small (eta squared $=.04$ ), thus age was not included in the analyses. The mean relationship duration was 16.6 months $(S D=18.18)$ with a range from 1 to 144 months, with only the psychologically victimized group having significantly longer relationships than the not psychologically victimized group, but the magnitude of the difference was small (eta squared $=.01$ ). For the purpose of testing the relations between the investment model variables and victimization, the sample was dichotomized on the basis of length of relationship, into shorter duration ( $0-12$ months inclusive; $\mathrm{n}=206,52.8$ percent) and longer duration (13 months or longer; $\mathrm{n}=184$, 47.2 percent). Second, descriptive statistics were computed, along with bivariate correlations between all variables. Third, for the women in the longer-duration group, we conducted a series of regression analyses to test the hypothesis that the relation between victimization and commitment was mediated by satisfaction, investment, and qualitative of alternatives, as predictors of sexual, physical, psychological, and overall victimization. Before performing regression analyses, we conducted a series of tests to assess whether the assumptions of linear regression were violated. Although the distributions for the Physical Assault and Sexual Coercion subscales were positively skewed, our sample size was sufficient to justify not performing a transformation (Hayes 2013). To handle missing data due to item non-response, we used the listwise deletion method, since the cases lost were less than 5 percent (Graham, Cumsille, and Elek-Fisk 2003).

\subsection{Frequency of Victimization and Bivariate Relations among Variables}

Table 1 presents a breakdown of each type of victimization, as well as patterns of co-occurrence for the total sample as well as for women in the shorter and longer relationship groups. Of 206 women whose relationship had lasted one year or less, 65 reported sexual victimization, (31.6 percent), 67 reported physical victimization (32.5 percent), and 139 reported psychological victimization (67.5 percent). There was also a pattern of significant co-occurrence between sexual and psychological victimization, $\chi^{2}=16.37$, 
$p<.001$; sexual and physical victimization, $\chi 2=18.28, p$ $<.001$; and psychological and physical victimization $\chi^{2}=$ $23.57, p<.001$. For the short duration group, 35 (16.9 percent) experienced all three forms of victimization.

Of 184 dating women whose relationship had lasted longer than a year, 42 reported sexual victimization $(22.8$ per- cent), 68 reported physical victimization (37 percent), and 146 reported psychological victimization (79.3 percent). For longer-duration relationships the pattern of co-occurrence was less pronounced, with only psychological and physical victimization co- occurring, $\chi^{2}=4.34, p<.05$. For the long duration group, 19 (10.3 percent) experienced all three forms of victimization.

Table 1: Mean frequency and percentage of types of victimization in the past year ( $N=184)$

\begin{tabular}{|c|c|c|c|c|c|c|c|c|c|c|}
\hline \multirow[b]{2}{*}{ Type of victimization } & \multicolumn{3}{|c|}{$\begin{array}{l}\text { Total } \\
\mathrm{N}=390\end{array}$} & \multicolumn{3}{|c|}{$\begin{array}{l}\text { Shorter duration } \\
\quad \mathrm{N}=206\end{array}$} & \multicolumn{4}{|c|}{$\begin{array}{l}\text { Longer duration } \\
\qquad \mathrm{N}=184\end{array}$} \\
\hline & $f(\%)$ & $M$ & $S D$ & $f(\%)$ & M & $S D$ & $f(\%)$ & M & $S D$ & $t$ \\
\hline None & 20.51 & - & - & 25.73 & - & - & 14.67 & - & - & - \\
\hline Only sexual & 2.82 & 3.50 & 2.01 & 3.88 & 2.71 & 1.79 & 1.63 & 5.33 & 1.15 & $-2.28 *$ \\
\hline Only physical & 3.33 & 3.18 & 1.88 & 2.91 & 4.16 & 1.94 & 3.80 & 2.00 & 1.00 & $2.24 *$ \\
\hline Only psychological & 31.53 & 4.51 & 3.94 & 27.18 & 3.94 & 3.75 & 36.41 & 4.98 & 3.77 & -1.52 \\
\hline Physical and psychological but not sexual & 17.18 & 16.13 & 15.65 & 12.62 & 10.95 & 6.63 & 22.28 & 19.17 & 18.47 & $-2.09 *$ \\
\hline Physical and sexual but not psychological & 0.26 & 4.00 & - & - & - & - & 0.54 & 4.00 & - & - \\
\hline Sexual and psychological but not physical & 10.51 & 9.48 & 5.64 & 10.68 & 8.89 & 6.19 & 10.32 & 10.60 & 4.50 & -.76 \\
\hline Sexual and physical and psychological & 13.85 & 40.31 & 32.06 & 16.99 & 44.93 & 36.55 & 10.32 & 31.93 & 20.15 & 1.31 \\
\hline Any & 79.49 & 13.26 & 19.63 & 74.27 & 14.18 & 12.35 & 85.33 & 12.35 & 14.18 & .78 \\
\hline
\end{tabular}

Note: ${ }^{*} p<.05$

Frequency (M): The items in CTS-R were rated on an eight-point frequency scale (never, once, twice, three to five times, six to ten times, eleven to twenty times, more than twenty times, and not in the past year but did happen before. Category 7 (not in the past year but did happen before) was coded as 0 , as suggested by Straus, since we wanted the victimization scores for the past twelve months. For the percentage. a 0/1 dichotomy was created.

Table 2 shows the bivariate correlations between all variables for the longer-duration group. As can be seen, all forms of victimization were significantly correlated (ranging from .24 to .75), with sexual victimization showing the weakest relation with physical and psychological. Correlations with total victimization suggest that all forms of abuse contributed to the total (for physical, $r=.93$; for psychological; $r=.90$, and for sexual, $r=.50$ ). Small but statis- tically significant correlations were found between the component variables of the Investment Model. Physical and psychological victimization, as well as total victimization, were significantly negatively correlated with satisfaction and commitment, but not correlated with investment or quality of alternatives. However, the correlations between sexual victimization and components of the Investment Model were non-significant. 
Table 2: Descriptives and bivariate correlations among predictor and outcome variables for longer relationship duration (Ns from 172 to 184)

\begin{tabular}{lcccccccccc}
\hline Variable & $\begin{array}{c}\text { Possible } \\
\text { range }\end{array}$ & $\begin{array}{c}\text { Actual } \\
\text { range }\end{array}$ & 1 & 2 & 3 & 4 & 5 & 6 & 7 & 8 \\
\hline sexual victimization (1) & $0-42$ & $0-20$ & 1.00 & $.36^{* *}$ & $.24^{* *}$ & $.50^{* *}$ & -.14 & -.07 & .08 & -.15 \\
physical victimization (2) & $0-72$ & $0-60$ & & 1.00 & $.75^{* *}$ & $.93^{* *}$ & $-.21^{* *}$ & .07 & .05 & $-.16^{*}$ \\
psychological victimization(3) & $0-48$ & $0-48$ & & & 1.00 & $.90^{* *}$ & $-.35^{* *}$ & .08 & .11 & $-.28^{* *}$ \\
total victimization (4) & $0-162$ & $0-108$ & & & & 1.00 & $-.28^{* *}$ & .06 & .08 & $-.22^{* *}$ \\
satisfaction(5) & $5-45$ & $7-45$ & & & & & 1.00 & $.42^{* *}$ & $-.40^{* *}$ & $.76^{* *}$ \\
investment(6) & $5-45$ & $5-45$ & & & & & & 1.00 &.$-35^{* *}$ & $.60^{* *}$ \\
quality of alternatives (7) & $5-45$ & $5-45$ & & & & & & & 1.00 & $-.58^{* *}$ \\
commitment (8) & $7-63$ & $15-63$ & & & & & & & & 1.00 \\
\hline
\end{tabular}

Note: ${ }^{* *} p<.01 ;{ }^{*} p<.05$

\subsection{Evaluation of the Investment Model}

The Investment Model, as proposed by Rusbult (1980, 1983), was tested for those women in the longer-duration subsample who reported at least one experience of victimization during the past year. The effects of predictors (satisfaction, investment, quality of alternatives) on commitment were examined. ${ }^{1}$ As shown in Table 3 , the model significantly predicted commitment, $F(3,163)=$ $128.19, p<.05$ with $R^{2}=.70$, indicating that 70 percent of the variance in commitment $(M=51.07 ; S D=13.63)$ was predicted by satisfaction $(M=35.75$; SD $=9.29)$, investment $(M=25.12 ; S D=9.78)$, and alternatives $(M=19.75$;
$S D=10.38)$. Satisfaction, investment, and alternatives uniquely explained 20 percent, 6 percent, and 6 percent of the variance, respectively. According to standardized coefficients $(\beta)$, there were significant positive relations between satisfaction and commitment $(\beta=.52)$, and investment and commitment $(\beta=.27)$. The association of alternatives to commitment remained significantly negative $(\beta=-.27)$. Women in longer-duration relationships reported greater investment, $t(1,381)=3.54, p<$ .05 , fewer alternatives, $t(1,377)=2.12, p<.05$, and greater commitment, $t(1,369)=2.98, p<.05$, than women in shorter-duration relationships.

Table 3: Regression analysis summary for commitment, test of Investment Model ( $N=167$ )

\begin{tabular}{lcccccccc}
\hline Variable & $B$ & $S E B$ & $\beta$ & $s r^{2}$ & $t$ & $p$ & $R$ & $R^{2}$ \\
\hline & & & & & & & .84 & .70 \\
Satisfaction & .77 & .07 & .52 & 20 & 10.53 & $.00^{*}$ & & \\
Investment & .38 & .07 & .27 & 6 & 5.61 & $.00^{*}$ & \\
Alternatives & -.35 & .06 & -.27 & 6 & -5.68 & $.00^{*}$ & \\
\hline
\end{tabular}

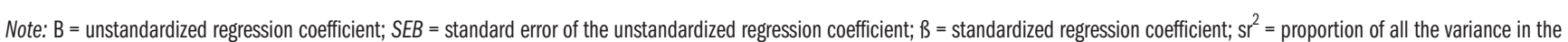
outcome variable associated with one predictor; $R=$ the multiple correlation coefficient; $R^{2}=$ the proportion of variance in the outcome accounted for by the predictor variable(s); $F$ ratio, whether the equation as a whole is statistically significant

$* p<.001$

1 We examined the alternative direction (commitment predicted victimization), and whether the relation was mediated by satisfaction, investment, or alternatives. The results were non-significant. 


\subsection{Relations between Investment Model Variables and Victimization}

We tested the hypothesis that the relation between total victimization and commitment would be mediated by satisfaction, investment, and quality of alternatives, using steps suggested by Baron and Kenny (1986), using the subset of the sample that reported a current relationship of longer than a year. First, the test of the investment model (see above) confirmed that all three variables predicted commitment. Second, we documented that total victimization predicted commitment, $F(1,161)=7.94, p<.05$, with $R^{2}=.05,(\beta=-.22, t=-2.82, p<.01)$. Third, a regression analysis examining total victimization as a predictor of satisfaction, investment, and quality of alternatives revealed that only satisfaction was significantly predicted by total victimization, $F(1,161)=13.50, p<.05$, with $R^{2}=$ $.08,(\beta=-.28, t=-3.68, p<.01)$. Thus, in the final step testing for mediation, we considered satisfaction as a mediator of the victimization-commitment relation. The final model was significant, $F(2,155)=96.24, p<.05$, with $R^{2}=.55$, and satisfaction, $\beta=.74, t=13.28, p=.001$, remained significant, indicating that satisfaction fully mediated the relation between total victimization and commitment. We repeated the same tests of mediation for each type of victimization. The same pattern was observed for psychological and physical victimization. For both forms of victimization, satisfaction fully mediated the relation between victimization and commitment. A Sobel test was performed to ascertain whether there was a significant decline in the relation between victimization and commitment when satisfaction was added as a mediator. Results revealed that satisfaction carried the influence of victimization $(z=2.23, p<.05$ for overall victimization, $z=2.97, p$ $<.05$ for psychological victimization, and $z=-1.68, p<.10$ for physical victimization). However, sexual victimization, although negatively related to satisfaction $(p=.07)$, was not related to commitment; therefore, we could not test for mediation. See Table 4 for a summary of all the regression analyses.

Table 4: Summary of mediation analyses with satisfaction as mediator between victimization within past year and commitment (Ns from 158 to 170)

\begin{tabular}{|c|c|c|c|c|c|}
\hline & & $B$ & SEB & $\beta$ & $R^{2}$ \\
\hline & Total victimization and commitment & & & & \\
\hline Step 1 & Total victimization & -.20 & .07 & $-.22 * *$ & $.05^{* *}$ \\
\hline \multirow[t]{4}{*}{ Step 2} & Total victimization & -.00 & .05 & $-.00^{\mathrm{ns}}$ & \\
\hline & Satisfaction & 1.09 & .08 & $.74^{* * *}$ & $.55^{* * *}$ \\
\hline & Sobel $z=2.23, p=.02$ & & & & \\
\hline & Psychological victimization and commitment & & & & \\
\hline Step 1 & Psychological victimization & -.53 & .14 & $-.28 * * *$ & $.08^{* * *}$ \\
\hline \multirow[t]{4}{*}{ Step 2} & Psychological victimization & -.02 & .09 & $-.01^{\mathrm{ns}}$ & \\
\hline & Satisfaction & .90 & .08 & $.61^{* * *}$ & $.65^{* * *}$ \\
\hline & Sobel $z=2.97, p=.00$ & & & & \\
\hline & Physical victimization and commitment & & & & \\
\hline Step 1 & Physical victimization & -.30 & .14 & $-.16^{*}$ & $.03^{*}$ \\
\hline \multirow[t]{3}{*}{ Step 2} & Physical victimization & .00 & .09 & $-.00^{\mathrm{ns}}$ & \\
\hline & Satisfaction & 1.12 & .08 & $.76^{* * *}$ & $.57 * * *$ \\
\hline & Sobel $z=-1.68, p=.09$ & & & & \\
\hline
\end{tabular}

Note: $\mathrm{B}=$ unstandardized regression coefficient; $\mathrm{SEB}=$ standard error of the unstandardized regression coefficient; $\beta=$ standardized regression coefficient; $\mathrm{R} 2$ = the proportion of variance in the outcome accounted for by the predictor variable(s). $* * * p<.001 ; * p<.01 ; * p<.05$ 


\section{Discussion}

The present study revealed several significant aspects of dating violence among Turkish students. First, within longer-duration relationships (on average sixteen months up to survey date), a surprisingly high percentage of women (85.4 percent) had experienced at least one instance of dating violence, with psychological abuse being the most frequently experienced form $(M=6.21)$ (by over half the sample: 79.3 percent) and sexual victimization being the least frequently experienced $(\mathrm{M}=1.12)(22.8$ percent). Physical victimization was intermediate $(\mathrm{M}=$ $2.92,37$ percent). Second, the percentage of Turkish women who experienced some form of victimization was higher than typically reported in Western samples, especially for just the past twelve months rather than lifetime. For example, college women from ten European countries, Canada, and the United States reported physical victimization rates ranging from 12.7 percent (Sweden) to 31.5 percent (United Kingdom) and sexual victimization rates ranging from 9.2 percent (Netherlands) to 42 percent (Greece), in the previous twelve months (Chan et al. 2008). Similar to the present study, Toplu and Hatipoğlu-Sümer (2011) found a high percentage of women reporting psychological abuse in a Turkish sample (77.4 percent). Additionally, frequent co-occurrence of multiple forms of victimization was reported in the present study, adding to a growing literature arguing for explicit attention to co-occurrence (Smith, White, and Holland 2003; White 2009). The present study is the first to report on co-occurrence of victimization among Turkish college women, and the first to include psychological victimization in the examination of co-occurrence. Additionally, the results indicate that women who experienced physical victimization were also at increased risk of experiencing psychological abuse, although the data cannot tell us if the various forms of victimization occurred during the same event or on different occasions during the relationship.

The present study confirms the validity of the Investment Model among Turkish college women. As hypothesized, satisfaction, investment, and quality of alternatives predicted commitment, increasing our confidence in using the model to understand dating violence among Turkish college women. In the present study, we examined the Invest- ment Model and victimization among only the subset of women who reported a current relationship lasting longer than one year, in order to ensure that the ratings of the Investment Model variables were associated with the perpetrator of the abuse. Our results did not fully replicate those of Rhatigan and Street (2005). Whereas they found a positive relation between investment and psychological abuse and a negative association between investment and physical abuse, we did not. However, like Rhatigan and Street (2005), the present study found that both forms of victimization were negatively associated with satisfaction, which mediated the relation between commitment and both psychological and physical victimization, as well as total victimization. We had expected that sexual victimization would also be related to commitment, as well as to satisfaction, investment, and quality of alternatives. However, it was not. It is possible that although a substantial percentage of the sample experienced sexual victimization, the mean frequencies were too low to detect the expected relations. Additionally, the measure of sexual victimization included both verbally coerced and physically forced sexual victimization. Hence, the degree of specificity may have been inadequate to uncover a relation between sexual victimization and various aspects of investment in a relationship.

\section{Limitations of the Study and Future Directions}

The present study had several limitations. First, the data were based on retrospective self-reporting. Participants were asked to remember dating violence occurrence within the past year, with the risk of memory distortion. Moreover, there is the risk of respondents concealing certain information. Secondly, the sample was a convenience sample (undergraduate and graduate students enrolled in the four universities in Ankara, Turkey). Therefore, the findings may not be generalizable or may be generalizable only to this population. Thirdly, although the results of the Sobel test indicated that satisfaction mediated the victimization/commitment relationship, the p-value for physical victimization did not reach the standard .05 level. This could be due to an inadequate sample size (the Sobel test works best with large samples) or it is possible that for physical victimization other factors, such as fear, might also mediate the relationship. Further research is recommended to explore this possibility. Finally, the study is 
cross-sectional/correlational in nature. Therefore, one cannot infer causality or establish temporal ordering from the findings. However, neither the Investment Model nor other theories of dating violence hypothesize that level of commitment would alter the risk of victimization. Additionally, preliminary analyses exploring the possibility that commitment might predict victimization indicated that this is unlikely, strengthening a tentative conclusion that victimization leads to less commitment as a result of less satisfaction in the relationship. However, longitudinal research will be necessary to gain a deeper understanding of the victimization/commitment relation.

Despite these limitations, the results add to the growing literature that has adopted the framework of the Investment Model to understand various facets of abusive relationships. This approach is promising for Turkish samples as well, given that the Investment Model appears valid for Turkish samples. There is a lack of literature regarding dat-

\section{References}

Akbalık-Doğan, Özge, and Ayda Büyükşahin-Sunal. 2011. Evliliklerde Olumlu Yanılsama: İlişki Bağlanımı ile Nedensellik ve Sorumluluk Yüklemeleri Arasındaki İlişkiler [Positive illusions in marriages: Relationships between relationship commitment and causality and responsibility attributions]. Türk Psikoloji Dergisi 26 (67): 70-82.

Altınay, Ayşe G., and Yeşim Arat. 2009. Violence against Women in Turkey. Istanbul: Punto.

Aslan, Dilek, Duygu Vefikuluçay, Simge Zeyneloğlu, Türküler Erdost, and Fehminaz Temel. 2008. Ankara'da iki Hemşirelik Yüksekokulu’nun birinci ve dördüncü sınıflarında okuyan öğrencilerin flört şiddetine maruz kalma, flört ilişkilerinde şiddet uygulama durumlarının ve bu konudaki görüşlerinin saptanması araştırması [Investigation of the views and prevalence of dating violence victimization and perpetration among freshmen and seniors in two schools of nursing in Ankara]. Ankara: Hacettepe Üniversitesi Kadın Sorunları Araştırma ve Uygulama Merkezi.

Baron, Ruben M., and David A. Kenny. 1986. The Moderator-Mediator Variable Distinction in Social Psychological Research: Conceptual, Strategic, and Statistical Considerations. Personality and Social Psychology 51:1173-82.

Büyükpahin, Ayda, Derya Hasta, and Selim Hovardaoðlu. 2005. İlişki İstikrarı Ölçeği: Geçerlik ve Güvenirlik Çalışması [Relationship stability (RSS): A study of validity and reliability]. Türk Psikoloji Yazıları 8 (16): 25-37.

Büyükpahin, Ayda, and Selim Hovardaoğlu. 2007. Yatırım Modelinin Bazı İlişkisel Değişkenler Yönünden İncelenmesi [Investigation of the investment model in terms of certain relational variables]. Türk Psikoloji Dergisi 22 (59): 69-86.

Büyükpahin, Ayda, and Nur Taluy. 2008. [Adaptation of commitment subscale of the investment model scale to Turkish conditions]. Unpublished raw data.

Cann, Arnie, and Tracy R. Baucom. 2004. Former Partners and New Rivals as Threats to a Relationship: Infidelity Type, Gender, and Commitment as Factors Related to Distress and Forgiveness. Personal Relationships 11 (3): 305-18. doi:10.1111/j.1475-6811.2004.00084.x ing violence in Turkey and no application of a relational perspective. Hence, our findings provide a foundation for additional studies. Future studies should extend the current findings by examining relationship termination. Rhatigan, Street, and Axsom (2006) have argued that the Investment Model may be one of the best theoretical frameworks for assisting victims of intimate partner violence and understanding factors associated with relationship termination. Based on the results of the present study, we suggest the possibility that the dissatisfaction women experience as a result of victimization would increase the chances of terminating the relationship. However, whether this would happen in dating relationships in Turkish culture, as has been documented in Western ones, remains to be determined. The cultural pressures on Turkish women to stay in even unsatisfactory relationships may be too strong for them to leave. Leaving the relationship may result in social sanctions due to sexual double standards applying to male and female sexuality and virginity.

Chan, Ko Ling, Murray A. Straus, Douglas A. Brownridge, Agnes Tiwari, and W. C. Leung. 2008. Prevalence of Dating Violence and Suicidal Ideation among Male and Female University Students Worldwide. Journal of Midwifery and Women's Health 53 (6): 529-37. doi:10.1016/j.jmwh.2008.04.016

Cok, Figen, and Lizbeth Ann Gray. 2007. Development of a Sex Education Programme for 12-year-old to 14-year-old Turkish Adolescents. Sex Education 7 (2): 127-41. doi:10.1080/14681810701264466

Drigotas, Stephen M., C. Annette Saftrom, and Tiffany Gentilia. 1999. An Investment Model Prediction of Dating Infidelity. Journal of Personality and Social Psychology 77 (3): 509-24.

Edwards, Katie M., Christine A. Gidycz, and Megan J. Murphy. 2011. College Women's Stay/Leave Decisions in Abusive Relationships: A Prospective Analysis of an Expanded Investment Model. Journal of Interpersonal Violence 26 (7): 1446-62. doi:10.1177/0886260510369131.

Eşsizoğlu, Altan, Aziz Yasan, Ejder Akgun Yildirim, Faruk Gurgen, and Mustafa Ozkan. 2011. Double Standard for Traditional Value of Virginity and Premarital Sexuality in Turkey: A University Students Case. Women Health 51 (2): 136-50. doi:10.1080/03630242.2011.553157

Etcheverry, Paul E., and Benjamin Le. 2005. Thinking about Commitment: Accessibility of Commitment and Prediction of Relationship Persistence, Accommodation, and Willingness to Sacrifice. Personal Relationships 12 (1): 103-23. doi:10.1111/j.1350-4126.2005.00104.x

Fisek, Guler Okman. 1982. Psychopathology and the Turkish Family: A Family Systems Theory Analysis. In Sex Roles, Family, and Community in Turkey, ed. Çiğdem Kağıtçıbaşı, 1st ed., 295-321. Bloomington, Indiana: Indiana University Press.

Graham, John W., Patricio E. Cumsille, and Elvira Elek-Fisk. 2001. Methods for Handling Missing Data. In Handbook of Psychology: Research Methods in Psychology, ed. John A. Schinka and Wayne F. Velicer, 1st ed., 87-114. New York: John Wiley.

Hayes, Andrew F. 2013. Introduction to Mediation, Moderation, and Conditional Process Analysis: A Regression-based Approach. New York: Guilford Press. 
Hortaçsu, Nuran, Sibel Kalaycioğlu, and Helga Rittersberger-Tiliç. 2003. Intrafamily Aggression in Turkey: Frequency, Instigation and Acceptance. Journal of Social Psychology 143 (2): 163-84. http://www.tandfonline.com/doi/ pdf/10.1080/00224540309598438

Katz, Jennifer, Stephanie Washington Kuffel, and Felisa A. Brown. 2006. Leaving a Sexually Coercive Dating Partner: A Prospective Application of Investment Model. Psychology of Women Quarterly 30 (3): 267-75.

Kelley, Harold H., and John W. Thibaut. 1978. Interpersonal Relations: A Theory of Interdependence. New York: Wiley.

Okutan, Nur, and Ayda Büyükşahin-Sunal. 2010. Romantik İlişkilerde Bağlanım: Dindarlık Algısı ve Romantik İlişkilerle İlgili Kalıpyargılar [Commitment in romantic relationships: Perceptions of religiosity and stereotypes about romantic relationships]. Türk Psikoloji Yazıları 13 (26): 80-88.

Özgür, Serap, and Diane Sunar. 1982. Social Psychological Patterns of Homicide in Turkey: A Comparison of Male and Female Convicted Murders. In Sex Roles, Family, and Community in Turkey, ed. Çiğdem Kağıtçıbaşı, 1st ed., 349-82. Bloomington, Indiana: Indiana University Press.

Rhatigan, Deborah L., and Amy E. Street. 2005. The Impact of Intimate Partner Violence on Decisions to Leave Dating Relationships: A Test of the Investment Model. Journal of Interpersonal Violence 20 (12): 1580-97. doi:10.1177/0886260505280344

Rhatigan, Deborah L., Amy E. Street, and Danny K. Axsom. 2006. A Critical Review of Theories to Explain Violent Relationship Termination: Implications for Research and Intervention. Clinical Psychology Review 26 (3): 321-45. doi:10.1016/j.cpr.2005.09.002

Rusbult, Carly E. 1980. Commitment and Satisfaction in Romantic Associations: A Test of the Investment Model. Journal of Experimental and Social Psychology 16 (2): 172-86. doi:10.1016/0022-1031(80)90007-4

Rusbult, Carly E. 1983. A Longitudinal Test of the Investment Model: The Development (and Deterioration) of Satisfaction and Commitments in Heterosexual Involvements. Journal of Personality and Social Psychology 45 (1): 101-17.

Rusbult, Carly E., and John M. Martz. 1995. Remaining in an Abusive Relationship: An Investment Model Analysis on Nonvoluntary Dependence. Personality and Social Psychology Bulletin 21 (6): 558-71. doi: $10.1177 / 0146167295216002$

Rusbult, Carly E., John M. Martz, and Christopher R. Agnew. 1998. The Investment Model Scale: Measuring Commitment level, Satisfaction Level, Quality of Alternatives, and Investment Size. Personal Relationships 5:357-91.
Rusbult, Carly E., Isabella M. Zembrodt, and Lawanna K. 1982. Exit, Voice, Loyalty, and Neglect: Responses to Dissatisfaction in Romantic Involvements. Journal of Personality and Social Psychology 43 (6): 1230-42.

Sakallı- Uğurlu, Nuray, and Peter Glick. 2003. Ambivalent Sexism and Attitudes toward Women Who Engage in Premarital Sex in Turkey. Journal of Sex Research 40 (3): 296-302.

Smith, Paige Hall, Jacquelyn W. White, and Lindsay J. Holland. 2003. A Longitudinal Perspective on Dating Violence among Adolescent and College-Age Women. American Journal of Public Health 93 (7): 1104-09.

Straus, Murray A. 2004. Prevalence of Violence against Dating Partners by Male and Female University Students Worldwide. Violence against Women 10 (7): 790-811. doi:10.1177/1077801204265552

Straus, Murray A., Sherry L. Hamby, Sue Boney-McCoy, and David B. Sugarman. 1996. The Revised Conflict Tactics Scale (CTS2): Development and Preliminary Psychometric Data. Journal of Family Issues 17 (3): 283-316. doi:10.1177/019251396017003001

Toplu, Ezgi, and Zeynep Hatipoglu-Sümer. 2011. Flört ilişkisinde şiddetin yaygınlığı ve türleri [Prevalence and types of dating violence]. Paper presented at the XI. Ulusal Psikolojik Danışma ve Rehberlik Kongresi [13th National Congress of Counseling and Guidance], October 3-5, Selçuk, İzmir.

Turhan, Ebru, Asuman Guraksin, and Tacettin Inandi. 2006. Validity and Reliability of the Turkish Version of the Revised Conflict Tactics Scales. Turkish Journal of Public Health 4 (1): 1-13.

Turkish Republic Prime Ministry, Directorate General on the Status of Woman. 2009. Domestic Violence against Women in Turkey. http://www.hips.hacet tepe.edu.tr/eng/dokumanlar/2008-TDVAW_Main_Report.pdf

Türkiye Büyük Millet Meclisi, İnsan Hakları İnceleme Komisyonu [Turkish Grand National Assembly, Commission for the Investigation of Human Rights]. 2012. Kadına ve Aile Bireylerine Yönelik Şiddeti İnceleme Raporu [Report of an Investigation on Violence against Woman and Domestic Violence].

http://www.tbmm.gov.tr/komisyon/insanhaklari/docs/2012/rapor lar/29_05_2012.pdf

White, Jacquelyn W. 2009. A Gendered Approach to Adolescent Dating Violence: Conceptual and Methodological Issues. Psychology of Women Quarterly 33:1-15.
Ezgi Toplu-Demirtaş

ezgi@metu.edu.tr
Zeynep Hatipoğlu-Sümer

zeynep@metu.edu.tr
Jacquelyn W. White

jwwhite@uncg.edu 